\title{
PUBLIC PRIVATE COMMUNITY PARTNERSHIP: POTENSI KETERLIBATAN MASYARAKAT DALAM PENGEMBANGAN WISATA EDUKASI STUDI KASUS: RUMAH ATSIRI INDONESIA
}

\author{
Yulia Nilam Ainun Lutfiyani \\ Prodi Arsitektur Fakultas Teknik \\ Universitas Muhammadiyah Surakarta \\ e-mail: nilamal96@gmail.com
}

\section{Dyah Widi Astuti}

Prodi Arsitektur Fakultas Teknik

Universitas Muhammadiyah Surakarta

e-mail: dyahwidi.dw@gmail.com

\begin{abstract}
ABSTRAK
Rumah Atsiri Indonesia merupakan wisata edukasi yang berada Dukuh Watusambang, Desa Pumbon, Kecamatan Tawangmangu, Kabupaten Karanganyar, berasal dari hasil restorasi Pabrik Minyak Atsiri "Citronella" Indonesia-Bulgaria tahun 1963. Rumah Atsiri Indonesia menginginkan suatu pengembangan yang baik untuk mencapai visi misi dan tujuannya sebagai ikon Desa Plumbon dan berperan dalam pemberdayaan masyarakat sekitar. Akan tetapi dalam pelaksanaannya Rumah Atsiri Indonesia memiliki permasalahan berupa keterbatasan lahan, hubungan yang kurang baik dengan masyarakat sekitar, dan pengolahan limbah yang kurang maksimal. Padahal arah dan ukuran keberhasilan pengembangan sangat ditentukan oleh kesinergian antar pihak pelaku pengembangan, hal ini sejalan dengan pendapat Penabulu Foundation Civil Society Resource Organization dalam bahasan isu strategis "Kemitraan Pemerintah-Swasta-Komunitas". Penelitian ini menggunakan metode analisis deskriptif kualitatif yang dilakukan dengan observasi, study literature dan wawancara dilengkapi dengan sample questioner wisatawan yang dianalisa secara kuantitatif dan dideskripsikan hasilnya. Hasil penelitian berupa rekomendasi bagi Rumah Atsiri Indonesia terkait tahapan yang dilakukan dalam mencapai kerjasama yang dapat dilakukan, dan pemetaan sentalisasi kegiatan berdasarkan potensi-potensi yang dimiliki Desa Plumbon. Kesimpulannya peran dan hubungan antara pembuat kebijakan (pemerintah), Rumah Atsiri Indonesia, dan masyarakat sangat mempengaruhi keberhasilan tujuan dan arah pengembangan yang akan dilakukan.
\end{abstract}

KATA KUNCI: Rumah Atsiri Indonesia, Desa Plumbon, potensi keterlibatan masyarakat, pemetaan sentralisasi kegiatan

\section{PENDAHULUAN}

Arsitektur merupakan bidang ilmu yang selalu berkembang baik dalam model bangunan, tipe bangunan, dan fungsi bangunan yang sejalan dengan kebutuhan kegiatan manusia dalam berkehidupan. Manusia memiliki berbagai kegiatan primer, sekunder, dan tersier. Tak jarang wadah kegiatan tersebut membutuhkan tempat yang memiliki bentuk, tipe, fungsi dan suasana tetentu karena bangunan berfungsi sebagai wadah kegiatan-kegiatan yang menempatkannya pada tempat yang khusus dan tertentu, hal ini sejalan dengan pendapat Geoffrey Broadbent (1980).

Salah satu kegiatan yang membutuhkan wadah khusus adalah rekreasi. Rekreasi bukanlah kegiatan primer, tetapi kegiatan ini memberikan pengaruh terhadap psikologis manusia. Berekreasi dapat melepaskan beban pikiran, melepas penat, mendapatkan feel yang baru, pengetahuan, dan pengalaman lain, sehingga seringkali rekreasi menghabiskan waktu dan biaya lebih. Rekreasi selalu berkaitan dengan tempat wisata. Saat ini banyak tempat wisata yang meyajikan berbagai kegiatan yang menarik dengan pemandangan yang indah, memberikan pengalaman edukasi, dan suasana yang berbeda di dalamnya. Salah satu tempat rekreasi yang menyajikan wisata berbasis wisata edukasi adalah Rumah Atsiri Indonesia.

Rumah Atsiri Indonesia berada di Jalan Watusambang, Dukuh Watusambang, Desa Plumbon, Kecamatan Tawangmangu, Kabupaten Karanganyar (lihat gambar 1). Rumah Atsiri yaitu tempat wisata edukasi, merupakan hasil restorasi bekas Pabrik Citronella Indonesia-Bulgaria, yang dibangun pada tahun 1963. Atas kerjasama pemerintah Indonesia dan Bulgaria, bangunan ini didukung menjadi pabrik penyedia minyak atsiri terbesar se-Asia pada masa Soekarno, antara tahun 1963-1967.

Kegiatan rekreasi edukasi yang dilakukan di Rumah Atsiri berupa sejarah Pabrik Citronella, macammacam jenis tanaman atsiri, cara pengolahan tanaman atsiri hingga menjadi produk dan eksperiamen kimiawi 
yang memanfaatkan tanaman atsiri. Kegiatan rekreasi yang lain adalah bersantai, berbelanja dan kuliner. Dalam pelaksanaanya, kegiatan tersebut diwadahi dalam beberapa bangunan dengan fungsi rumah kaca, tempat penyulingan, taman, toko merchandise dan resto.

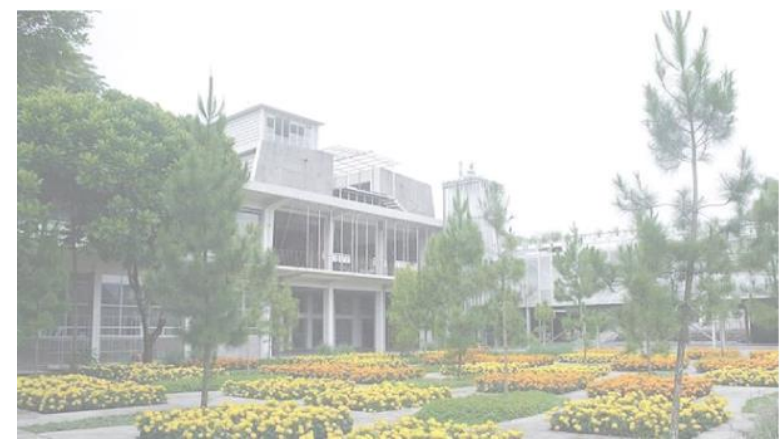

Gambar 1. Rumah Arsiri Indonesia di Karanganyar (sumber: dokumen penulis, 2018)

Rumah Atsiri Indonesia memiliki target pengembangan berdasarkan visi misi dan tujuan khususnya untuk menjadi ikon Desa Plumbon sebagai lembaga swasta yang berperan dalam pemberdayaan masyarakat di sekitarnya. Proses pewujudan visi misi dan tujuan Rumah Atsiri Indonesia tidak selalu berjalan mulus, banyak rintangan dan kendala yang dialami. Saat ini kendalanya adalah keterbatasan lahan untuk pengembangan kawasan Rumah Atsiri Indonesia, hubungan interaksi yang kurang baik dengan masyarakat, belum ada peran masyarakat di dalam kegiatanya, dan sistem pengolahan limbah yang belum maksimal dan belum dapat di-reused. Permasalahan tersebut didapatkan langsung dari pernyataan owner dan narasumber. Berdasarkan permasalahan tersebut, maka muncul pertanyaan penelitian sebagai berikut:

1. Apakah keterlibatan masyarakat dalam pengembangan wisata edukasi Rumah Atsiri Indonesia di Desa Plumbon tersebut memungkinkan?

2. Bila memungkinkan, bagaimana programprogram yang potensial untuk ditindaklanjuti?

Tujuan penelitian ini antara lain:

1. Mengetahui potensi dan kelemahan yang dimiliki oleh lingkungan sekitar Rumah Atsiri Indonesia

2. Mengetahui kemungkinan kerjasama yang dapat dilakukan oleh Rumah Atsiri Indonesia dengan masyarakat sekitarnya

3. Mencari penyelesaian dari permasalahan yang dihadapi oleh Rumah Atsiri Indonesia

4. Mengetahui aspek apa saja yang harus ditekankan dan dipenuhi oleh Rumah Atsiri Indonesia agar dapat mencapai visi misi dan tujuannya
5. Memberikan masukan berupa saran dan rekomendasi untuk pengembangan Rumah Atsiri Indonesia.

Sasaran yang diharapkan adalah suatu gagasan dan masukan dalam pengembangan Rumah Atsiri Indonesia sebagai wisata edukasi yang berkembang dan melibatkan peran masyarakat di sekitarnya.

Pembahasan yang dilakukan berupa peninjauan secara menyeluruh keadaan Rumah Atsiri Indonesia, masyarakat dan lingkungan sekitarnya, pandangan, responsi dan harapan masyarakat sekitar dan wisatawan Rumah Atsiri Indonesia, dan peninjauan lebih lanjut tentang rencana daerah setempat dalam pengelolaan Desa Plumbon.

\section{TINJAUAN PUSTAKA \\ Wisata Edukasi}

Pariwisata pendidikan dimaksudkan sebagai suatu program dimana peserta kegiatan melakukan perjalanan wisata pada suatu tempat tertentu dalam suatu kelompok dengan tujuan utama mendapatkan pengalaman belajar secara langsung terkait dengan lokasi yang dikunjungi (Rodger, 1998: 28). Manfaat wisata edukasi yaitu (1) Memancing minat seorang anak terhadap hal tertentu, (2) Menambah informasi yang didapatkan di sekolah, (3) Pengalaman yang nyata dan benar-benar dialami secara langsung oleh anak, (4) Wawasan dan pengetahuan akan bertambah, (5) Menambah ilmu dan pengetahuan anak serta menambah perbendaharaan kata bagi anak, (6) Kemampuan bersosialisasi meningkat, (7) Sikap menghargai karya maupun jasa orang lain akan tertanam, (8) Anak lebih kreatif dan tidak pasif.

Macam-macam wisata edukasi antara lain (1) Wisata Edukasi Science (ilmu pengetahuan), berbasis kepada pendidikan ilmu pengetahuan, (2) Wisata Edukasi Sport (olahraga), berbasis kepada pendidikan secara fisik olahraga, (3) Wisata Edukasi Culture (kebudayaan), diantaranya pendidikan kebudayaan dalam bidang seni, adat istiadat dan lain yang berhubungan dengan kebudayaan, (4) Wisata Edukasi Agrobisnis, berbasis kepada pendidikan agro atau pertanian dan peternakan yang juga merupakan bisnis dari suatu perusahaan maupun perseorangan.

\section{Desa Wisata}

Desa wisata adalah suatu bentuk integrasi antara atraksi, akomodasi dan fasilitas pendukung yang disajikan dalam suatu struktur kehidupan masyarakat yang menyatu dengan tata cara dan tradisi yang berlaku. (Nuryanti, 1993). Menurut Gumelar (2010), terdapat 4 komponen Desa Wisata yaitu (1) Keunikan, keaslian, sifat khas, (2) Letaknya berdekatan dengan daerah alam yang luar biasa, (3) Berkaitan dengan kelompok atau masyarakat berbudaya yang secara hakiki menarik minat pengunjung, (4) Memiliki 
peluang untuk berkembang baik dari sisi prasarana dasar, maupun sarana lainnya. Syarat desa wisata menurut James J. Spillane (1994: 63-72) antara lain (1)Attractions (daya tarik) yang dapat digolongkan menjadi site atractions dan event attractions, (2) Facilities, merupakan fasilitas yang diperlukan oleh pengunjung dalam melakukan kegiatan, (3) Infrastructure (infrastruktur), (4) Transportation (transportasi), (5) Hospitality (keramahtamahan).

\section{Public Privat Community Partnership PPCP}

Pendekatan kemitraan antara pemerintah swasta-masyarakat (Public - Private - Community Partnership - PPCP) merupakan model operasional sinergis untuk mencapai pembangunan secara berkelanjutan dimana tiga pihak secara bersama-sama mengembangkan unit usaha atau layanan yang saling menguntungkan dan memberikan manfaat sebesarbesarnya bagi masyarakat luas. Dalam kerangka tersebut, sektor swasta akan mendapatkan keuntungan dalam jangka panjang dengan inklusifitas berimbang antara rantai produsen dan konsumen, sektor publik akan mendapatkan keuntungan dengan tambahan sumber daya dan nilai investasi serta keterjaminan partisipasi dan kepemilikan para pihak; sedangkan masyarakat akan memperoleh manfaat dengan perolehan keterampilan, pengetahuan dan teknologi baru (Penabulu Foundation, 2015).

\section{Pemberdayaan Masyarakat pada Desa Wisata}

Pemberdayaan masyarakat sebagai terjemah dari kata "empowerment" mulai ramai digunakan dalam bahasa sehari-hari di Indonesia bersama-sama dengan istilah "pengentasan kemiskinan", yang digulirkan pemerintah Indonesia dalam Program Inpres No.5/1993 yang kemudian lebih dikenal sebagai Inpres Desa Tertinggal (IDT). Pemberdayaan adalah sebagai upaya untuk memberikan daya atau penguatan kepada masyarakat. Pemberdayaan masyarakat merupakan upaya untuk meningkatkan harkat dan martabat lapisan masyarakat yang dalam kondisi sekarang tidak mampu untuk melepaskan diri dari perangkap kemiskinan dan keterbelakangan. Contoh pemerdayaan masyarakat pada Desa Wisata yang telah terjadi dan sukses antara lain Desa Cinangeng, Saung Mang Udjo, dan Wayang Village. Desa wisata tersebut memiliki keberhasilan dalam pemberdayaan masyarakat. Keberhasilan itu dipengaruhi oleh aktivitas masyarakat, kualitas sumber daya manusia, komunitas pemuda, dan ramah tamah masyarakat.

\section{METODE PENELITIAN}

Penelitian ini menggunakan metode kualitatif dan kuantitatif. Data dan analisis dijabarkan secara deskriptif terhadap kejadian, fenomena, atau keadaan sosial. Metode kuantitatif digunakan untuk memperoleh data yang berbentuk angka atau data kualitatif yang diangkakan. Penggunaan metode kuantitatif hanya digunakan sebagai pendukung dalam perhitungan hasil sampling agar hasil dapat terbaca.

Tabel 1. Subyek Penelitian

\section{Fokus 1 : Rumah Atsiri Indonesia \\ Definisi : Tempat wisata yang berada di Jl. Watusambang, Dukuh Watusamban, Desa Plumbon, Kecamatan Tawangmangu, Kabupaten Karanganyar, yang memiliki kegiatan rekreasi berbasis edukasi. Pada pengembangan kedepan, Rumah Atsiri Indonesia menginginkan suatu bentuk pengembangan yang melibatkan peran masyarakat guna mencapai visi misi dan tujuannya. \\ Aspek : 1) Daya tarik. Terdiri dari sejarah \\ yang arsitektur, dan wahana kegiatan \\ dituju 2) Fasilitas \\ 3) Aksesibilitas. Terdiri dari aksesibilitas difabel, papan petunjuk arah}

Fokus 2 Desa Plumbon

Definisi : Merupakan suatu desa yang berada di Kecamatan Tawangmangu, Kabupaten Karanganyar. Desa ini bukanlah desa wisata, akan tetapi kondisi fisik lingkungan, kebudayaan, tradisi dan masyarakat di dalamnya berpotensi untuk mewujudkan Desa Plumbon sebagai desa wisata.

Aspek : 1) Daya tarik, terdiri dari sejarah, yang arsitektur, kuliner, kerajinan, budaya dituju dan bentang alam.

2) Fasilitas

3) Aksesibilitas, terdiri dari jalan jalur utama, jalan jalur pendukung, jalan jalur alternative, aksesibilitas difabel, sarana transportasi, petunjuk arah.

4) Infrastruktur, terdiri dari listrik atau penerangan, pengairan, jaringan komunikasi, jasa kesehatan.

5) Respon dan antusiasme masyarakat, terdiri dari kondisi SDM, aktivitas masyarakat, aktivitas pemuda, ramah taman masyarakat

\section{Metode Pengumpulan Data}

Data yang dibutuhkan dalam penelitian ini terdiri dari 2 data yaitu data primer dan data sekunder, yang dikumpulkan dengan cara:

1. Observasi, hal-hal yang diamati saat observasi yaitu: (a) Kondisi kawasan Rumah Atsiri Indonesia, meliputi kondisi fisik bangunan, ruangan, fasilitas, dan pengguna, kegiatan yang dilakukan, suasana dan kenyamanan, dan (b) 
Kawasan di sekitar Rumah Atsiri Indonesia, meliputi pencapaian terhadap Rumah Atsiri Indonesia, failitas umum, landmark dan bentang alam, pengguna kawasan di sekitar Rumah Atsiri Indonesia, kegiatan yang dilakukan di kawasan sekitar Rumah Atsiri Indonesia

2. Study Literatur

3. Interview (wawancara)

4. Questioner.

\section{Metode Analisa Data}

Analisis data pada penelitian ini dilakukan secara deskriptif kualitatif dengan menggunakan data berupa teks, persepsi, opini dan bahan tertulis lainnya. Selain itu digunakan juga metode analisis SWOT (strength, weakness, opportunity, treathness) yaitu suatu teknik yang digunakan untuk mengidentifikasi masalah melalui penguraian dan pemetaan: (1) Kekuatan (strengths), merupakan indikator yang diisi dengan menjabarkan kelebihan-kelebihan yang dimiliki oleh komponen sekitar Rumah Atsiri Indonesia yang dijadikan sebagai pendukung tewujudnya wisata edukasi yang berkembang dan berkesinambungan dengan masyarakat seitar, (2) Peluang (Opportunities), merupakan indikator yang diisi dengan menjabarkan hal-hal yang berguna untuk membuka peluang dalam terwujudnya wisata edukasi yang berkembang dan berkesinambungan dengan masyarakat seitar, (3) Kelemahan (weakness), merupakan indikator yang diisi dengan menjabarkan faktor-faktor yang kurang mendukung terwujudnya wisata edukasi yang berkembang dan berkesinambungan dengan masyarakat sekitar, (4) Ancaman (threatnesss), merupakan indikator yag diisi dengan menjabarkan faktor-faktor yang berpotensi tidak dapat terwujudnya wisata edukasi yang berkembang dan berkesinambungan dengan masyarakat sekitar. Skema analisis SWOT seperti dalam gambar 2 berikut ini:

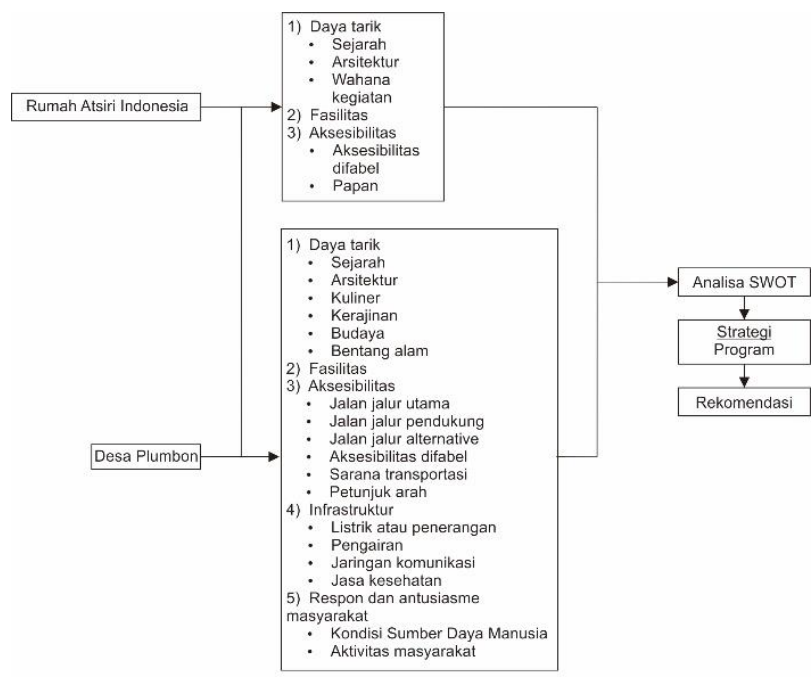

Gambar 2. Fokus Analisa SWOT

(sumber: dokumentasi penulis (2018)

\section{HASIL PENELITIAN DAN PEMBAHASAN}

\section{Hasil Wawancara}

Sejarah mencatat bahwa Rumah Atsiri Indonesia berawal dari kesukaan owner terhadap tanaman atsiri. Visi Rumah Atsiri Indonesia menjadi penggerak dalam pengembangan Minyak Atsiri khususnya sereh wangi (Java Citronella) di Tawangmangu dan sekitarnya melalui pemberdayaan untuk kesejahteraan stakeholder dan masyarakat pada umumnya, dengan misi mengembangkan pendidikan, melakukan pelatihan, melakukan riset dan pengembangan, melakukan Produksi hilirisasi produk-produk Atsiri, dan pengembangan sektor pariwisata. Tujuan didirikan Rumah Atsiri Indonesia untuk melestarikan keberadaan Pabrik Citronella bersamaan dengan keinginan untuk memberdayakan masyarakat sekitar dan mencari peluang bisnis dalam bidang wisata dengan dasar pendirian pada area tersebut sudah tidak boleh digunakan sebagai area industri. Tujuan tersebut sejalan dengan tujuan Desa Plumbon dalam pemberdayaan masyarakat. Kendala dalam mendirikan dan pengoperasian Rumah Atsiri Indonesia adalah mendidik staff dan pegawai agar sesuai dengan SOP. Dalam pelaksanakan kegiatan Rumah Atsri Indonesia belum terjalin kerjasama dan interaksi yang intensif dengan masyarakat sekitar, dan manfaat keberadaanya masih belum dirasakan. Respon masyarakat sangat baik terhadap berdirinya Rumah Atsiri Indonesia, mereka berharap perkembangan Rumah Atsiri Indonesia dapat memberikan dampak yang positif dan menguntungkan.

\section{Hasil Respondensi Sampling}

Wisatawan mayoritas berasal dari luar kota, datang bersama orang lain dengan tujuan rekreasi. Kebanyakan dari mereka mengetahui Rumah Atsiri Indonesia dari media sosial. Informasi yang didapatkan cukup untuk melakukan perjalanan dan kegiatan disana. Beberapa wisatawan mengalami kesulitan dalam perjalanan dikarenakan macet dan penanda arah yang kurang jelas. Pengunjung merasa kegiatan di Rumah Atsiri menyenangkan, edukatif dan bermanfaat. Fasilitasnya dirasa cukup lengkap namun perlu adanya pembenahan dan pelengkapan lebih lanjut. Kebanyakan wisatawan tertarik untuk mampir disebabkan paket wisata ke tempat lain.

\section{Analisa SWOT \\ Analisa Daya tarik (Attraction)}

Table 2. Analisa SWOT daya tarik (attraction)

\begin{tabular}{|c|c|c|c|c|}
\hline $\begin{array}{l}\text { Daya } \\
\text { tarik } \\
\text { (Atrac } \\
\text { tions) } \\
\end{array}$ & $\begin{array}{l}\text { Kekuatan } \\
\text { (Strengths) }\end{array}$ & $\begin{array}{l}\text { Kelemahan } \\
\text { (Weakness) }\end{array}$ & $\begin{array}{l}\text { Peluang } \\
\text { (Opportuni } \\
\text { ties) }\end{array}$ & $\begin{array}{l}\text { Ancaman } \\
\text { (Threatness) }\end{array}$ \\
\hline Sejarah & $\begin{array}{l}\text { Sejarah Rumah } \\
\text { Atsiri Indonesia } \\
\text { mencatat } \\
\text { bahwa }\end{array}$ & $\begin{array}{l}\text { Tidak banyak } \\
\text { yang tahu } \\
\text { bahwa pada } \\
\text { jaman }\end{array}$ & $\begin{array}{l}\text { Sejarah masa } \\
\text { lalu yaitu } \\
\text { keterkaitan } \\
\text { masyarakat, }\end{array}$ & $\begin{array}{l}\text { Masyarakat } \\
\text { masih } \\
\text { memiliki } \\
\text { pandangan }\end{array}$ \\
\hline
\end{tabular}




\begin{tabular}{|c|c|c|c|c|}
\hline $\begin{array}{l}\text { Daya } \\
\text { tarik } \\
\text { (Atrac } \\
\text { tions) }\end{array}$ & $\begin{array}{l}\text { Kekuatan } \\
\text { (Strengths) }\end{array}$ & $\begin{array}{l}\text { Kelemahan } \\
\text { (Weakness) }\end{array}$ & $\begin{array}{l}\text { Peluang } \\
\text { (Opportuni } \\
\text { ties) }\end{array}$ & $\begin{array}{l}\text { Ancaman } \\
\text { (Threatness) }\end{array}$ \\
\hline & $\begin{array}{l}\text { masyarakat } \\
\text { Desa Plumbon } \\
\text { dan sekitarnya } \\
\text { sangat } \\
\text { berperan } \\
\text { sebagai } \\
\text { pemasok bahan } \\
\text { baku produksi } \\
\text { di Pabrik } \\
\text { Citronella }\end{array}$ & $\begin{array}{l}\text { tersebut } \\
\text { Pabrik } \\
\text { Citronella } \\
\text { membutuhkan } \\
\text { peran } \\
\text { masyarakat } \\
\text { sekitar } \\
\text { sebagai } \\
\text { pemasok } \\
\text { bahan baku } \\
\text { produksi. }\end{array}$ & $\begin{array}{l}\text { maka ada } \\
\text { kemungkinan } \\
\text { bahwa } \\
\text { kerjasama } \\
\text { antar Rumah } \\
\text { Atsiri } \\
\text { Indonesia } \\
\text { akan dapat } \\
\text { dicapai } \\
\text { dengan } \\
\text { mudah. }\end{array}$ & $\begin{array}{l}\text { yang } \\
\text { tertutup } \\
\text { terhadap } \\
\text { Rumah Atsiri } \\
\text { Indonesia. }\end{array}$ \\
\hline Arsitektur & $\begin{array}{l}\text { Arsitektur } \\
\text { Rumah Atsiri } \\
\text { Indonesia } \\
\text { sangat unik, } \\
\text { dengan } \\
\text { mempertahank } \\
\text { an fasad lama } \\
\text { Pabrik } \\
\text { Citronella dan } \\
\text { menerapkan } \\
\text { greenship } \\
\text { building di } \\
\text { dalamnya. } \\
\text { Arsitektur Desa } \\
\text { Plumbon } \\
\text { umumnya } \\
\text { berupa rumah } \\
\text { joglo }\end{array}$ & $\begin{array}{l}\text { Arsitektur } \\
\text { Rumah Atsiri } \\
\text { Indonesia } \\
\text { tidak konteks } \\
\text { terhadap } \\
\text { arsitektur di } \\
\text { sekitarnya. } \\
\text { Pemukiman } \\
\text { Desa Plumbon } \\
\text { sudah } \\
\text { berubah, } \\
\text { menjadi } \\
\text { rumah } \\
\text { modern. }\end{array}$ & $\begin{array}{l}\text { Dapat } \\
\text { dimunculkan } \\
\text { kembali } \\
\text { arsitektur } \\
\text { yang telah } \\
\text { hilang yang } \\
\text { dapat } \\
\text { dijadikan } \\
\text { sebagai } \\
\text { identitas. }\end{array}$ & $\begin{array}{l}\text { Masyarakat } \\
\text { sudah } \\
\text { terlanjur } \\
\text { memiliki } \\
\text { pandangan } \\
\text { bahwa } \\
\text { seiring } \\
\text { berkembang } \\
\text { nya zaman } \\
\text { semua akan } \\
\text { berubah } \\
\text { termasuk } \\
\text { merubah } \\
\text { gaya } \\
\text { arsitektur } \\
\text { mereka } \\
\text { bahkan } \\
\text { tanpa sisa. }\end{array}$ \\
\hline Kuliner & $\begin{array}{l}\text { Kuliner di } \\
\text { Rumah Atsiri } \\
\text { Indonesia } \\
\text { merupakan } \\
\text { kuliner modern } \\
\text { yang } \\
\text { memanfaatkn } \\
\text { penggunaan } \\
\text { tanaman atsiri } \\
\text { di dalam cita } \\
\text { rasanya. } \\
\text { Kuliner } \\
\text { unggulan di } \\
\text { Desa Plumbon } \\
\text { dari olahan } \\
\text { tanaman atsiri. }\end{array}$ & $\begin{array}{l}\text { Masih banyak } \\
\text { wisatawan } \\
\text { yang belum } \\
\text { mengenal dan } \\
\text { mengetahui } \\
\text { cara } \\
\text { pembuatan } \\
\text { kuliner } \\
\text { makanan khas } \\
\text { Desa Plumbon } \\
\text { sebagai desa } \\
\text { tempat } \\
\text { berdirinya } \\
\text { Rumah Atsiri } \\
\text { Indonesia. }\end{array}$ & $\begin{array}{l}\text { Dapat } \\
\text { dilakukan } \\
\text { saling } \\
\text { mengenal } \\
\text { antar kuliner } \\
\text { dan } \\
\text { menciptakan } \\
\text { pengembang } \\
\text { an kuliner, } \\
\text { sehingga } \\
\text { dapat } \\
\text { membuka } \\
\text { peluang pasar } \\
\text { yang baru. }\end{array}$ & \\
\hline Kerajinan & $\begin{array}{l}\text { Beberapa } \\
\text { kerajinan di } \\
\text { Rumah Atsiri } \\
\text { Indonesia } \\
\text { mengadopsi } \\
\text { dari kerajinan } \\
\text { sekitar. }\end{array}$ & $\begin{array}{l}\text { Pemasaran } \\
\text { kerajinan desa } \\
\text { didistribusikan } \\
\text { keluar desa. }\end{array}$ & $\begin{array}{l}\text { Pengembang } \\
\text { an kerajinan } \\
\text { desa untuk } \\
\text { membuaka } \\
\text { peluang pasar } \\
\text { baru di } \\
\text { Rumah Atsiri } \\
\text { Indonesia. }\end{array}$ & $\begin{array}{l}\text { Masih belum } \\
\text { ada } \\
\text { ketertarikan } \\
\text { masyarakat } \\
\text { kearah } \\
\text { tersebut. }\end{array}$ \\
\hline Budaya & $\begin{array}{l}\text { Kebudayaan } \\
\text { rakyat berupa } \\
\text { tari, karawitan } \\
\text { dan wayang } \\
\text { berkembang di } \\
\text { Desa Plumbon } \\
\text { digelar di } \\
\text { lapangan desa } \\
\text { dan dibuka } \\
\text { untuk umum. }\end{array}$ & $\begin{array}{l}\text { Kebudayaan } \\
\text { yang ada } \\
\text { hanya digelar } \\
\text { ketika ada } \\
\text { orang hajatan } \\
\text { (hanya waktu } \\
\text { waktu } \\
\text { tertentu saja) }\end{array}$ & $\begin{array}{l}\text { Kebudayaan } \\
\text { tersebut } \\
\text { dapat } \\
\text { menjadi salah } \\
\text { satu } \\
\text { pertunjukan } \\
\text { guna } \\
\text { menghibur } \\
\text { wisatawan. }\end{array}$ & $\begin{array}{l}\text { Banyak } \\
\text { wisatawan } \\
\text { luar kota } \\
\text { kurang } \\
\text { paham } \\
\text { dengan } \\
\text { Bahasa } \\
\text { Jawa. }\end{array}$ \\
\hline $\begin{array}{l}\text { Bentang } \\
\text { alam }\end{array}$ & $\begin{array}{l}\text { Desa Plumbon } \\
\text { memiliki } \\
\text { bentang alam } \\
\text { yang masih } \\
\text { alami dalam } \\
\text { bentuk } \\
\text { perkebunan, } \\
\text { persawahan, } \\
\text { bukit, dan mata } \\
\text { air. }\end{array}$ & - & $\begin{array}{l}\text { Kemurnian } \\
\text { pemandang } \\
\text { an alam } \\
\text { dapat } \\
\text { digunakan } \\
\text { sebagai } \\
\text { keunggulan } \\
\text { yang menarik } \\
\text { minat } \\
\text { wisatawan. }\end{array}$ & - \\
\hline
\end{tabular}

Analisa Fasilitas (Facilities)

Table 3. Analisa SWOT fasilitas (facilities)

\begin{tabular}{|c|c|c|c|c|}
\hline $\begin{array}{l}\text { Fasilitas } \\
\text { (Atract } \\
\text { ions) }\end{array}$ & $\begin{array}{l}\text { Kekuatan } \\
\text { (Strengths) }\end{array}$ & $\begin{array}{l}\text { Kelemahan } \\
\text { (Weakness) }\end{array}$ & $\begin{array}{l}\text { Peluang } \\
\text { (Opportunit } \\
\text { ies) }\end{array}$ & $\begin{array}{l}\text { Ancaman } \\
\text { (Threatness) }\end{array}$ \\
\hline $\begin{array}{l}\text { Fasilitas } \\
\text { Rumah } \\
\text { Atsiri } \\
\text { Indonesia }\end{array}$ & $\begin{array}{l}\text { Fasilitas di } \\
\text { Rumah Atsiri } \\
\text { Indonesia } \\
\text { sudah cukup } \\
\text { lengkap. }\end{array}$ & $\begin{array}{l}\text { Fasilitas masih } \\
\text { tahap } \\
\text { pembangunan: } \\
\text { museum, } \\
\text { tempat spa, } \\
\text { mushola. } \\
\text { Fasilitas yang } \\
\text { belum ada }\end{array}$ & $\begin{array}{l}\text { Banyak } \\
\text { wisatawan } \\
\text { berkunjung } \\
\text { dan } \\
\text { memberi } \\
\text { masukan } \\
\text { untuk } \\
\text { perbaikan }\end{array}$ & $\begin{array}{l}\text { Lahan } \\
\text { Rumah Atsiri } \\
\text { Indonesia } \\
\text { yang } \\
\text { terbatas. }\end{array}$ \\
\hline
\end{tabular}

\begin{tabular}{lllll}
\hline penginapan, & $\begin{array}{l}\text { dan } \\
\text { outdoor play } \\
\text { ground, dan } \\
\text { sitting group. }\end{array}$ & $\begin{array}{l}\text { gengemban fasilitas } \\
\text { yang ada. }\end{array}$ & \\
\hline Fasilitas & Fasilitas desa & Tidak ada & Dilakukan & Pengadaan \\
Desa & lengkap untuk & fasilitas yang & peninjauan & dan \\
Plumbon & memenuhi & menunjang & lebih lanjut & pengemban \\
& kebutuhan & keberadaan & untuk & gan fasilitas \\
& warganya & wisatawan & membuat & yang tidak \\
& sarana & secara efektif. & fasilitas & mengganggu \\
& pendidikan, & & yang & keberadaan \\
& posyandu, & & mendukung & bentang \\
& & & keberadaan & alam di Desa \\
& subterminal, & & wisatawan. & Plumbon \\
& masjid, balai & & & \\
desa, dan balai & & & \\
pertemuan. & & &
\end{tabular}

Analisa Aksesibilitas (Accesibilities)

Table 4. Analisa SWOT aksesibilitas (accesibilities)

\begin{tabular}{|c|c|c|c|c|}
\hline $\begin{array}{l}\text { Aksesibilitas - } \\
\text { Accesibilities }\end{array}$ & $\begin{array}{l}\text { Kekuatan - } \\
\text { Strengths }\end{array}$ & $\begin{array}{l}\text { Kelemahan } \\
\text { - Weakness }\end{array}$ & $\begin{array}{l}\text { Peluang - } \\
\text { Opportunities }\end{array}$ & $\begin{array}{l}\text { Ancaman - } \\
\text { Threatness }\end{array}$ \\
\hline $\begin{array}{l}\text { Jalan jalur } \\
\text { utama }\end{array}$ & $\begin{array}{l}\text { Jalur utama } \\
\text { mudah } \\
\text { dilewati. } \\
\text { Aspal, hampir } \\
\text { tidak ada } \\
\text { kerusakan }\end{array}$ & $\begin{array}{l}\text { Jalan } \\
\text { berkelok } \\
\text { dan naik } \\
\text { turun. }\end{array}$ & $\begin{array}{l}\text { Sesuai tujuan } \\
\text { sesuai waktu } \\
\text { tempuh. }\end{array}$ & $\begin{array}{l}\text { Rawan } \\
\text { kecelakaan. }\end{array}$ \\
\hline $\begin{array}{l}\text { Jalan jalur } \\
\text { pendukung }\end{array}$ & $\begin{array}{l}\text { Jalur } \\
\text { pendukung } \\
\text { berupa jalan } \\
\text { desa yang } \\
\text { memudahkan } \\
\text { dan } \\
\text { mempercepat } \\
\text { menuju desa } \\
\text { lain }\end{array}$ & $\begin{array}{l}\text { Jalan naik } \\
\text { turun tajam } \\
\text { dan sempit. }\end{array}$ & $\begin{array}{l}\text { Memudahkan } \\
\text { akses antar } \\
\text { desa. }\end{array}$ & $\begin{array}{l}\text { Rawan } \\
\text { kecelakaan. }\end{array}$ \\
\hline $\begin{array}{l}\text { Jalan jalur } \\
\text { alternatif }\end{array}$ & $\begin{array}{l}\text { Jalur } \\
\text { alternatif ini } \\
\text { digunakan } \\
\text { ketika ada } \\
\text { halangan } \\
\text { pada jalur } \\
\text { utama. }\end{array}$ & $\begin{array}{l}\text { Jalan } \\
\text { memutar } \\
\text { dan jarak } \\
\text { tempuh } \\
\text { lebih jauh. }\end{array}$ & - & $\begin{array}{l}\text { Sampai } \\
\text { tujuan tidak } \\
\text { tepat waktu. }\end{array}$ \\
\hline $\begin{array}{l}\text { Aksesibilitas } \\
\text { difabel }\end{array}$ & $\begin{array}{l}\text { Pada Rumah } \\
\text { Atsiri } \\
\text { Indonesia } \\
\text { sudah } \\
\text { tersedia } \\
\text { akses difabel } \\
\text { sesuai } \\
\text { dengan } \\
\text { standar. }\end{array}$ & $\begin{array}{l}\text { Belum ada } \\
\text { fasilitas } \\
\text { ramah } \\
\text { difabel di } \\
\text { desa } \\
\text { setempat. }\end{array}$ & $\begin{array}{l}\text { Kaum difabel } \\
\text { tetap dapat } \\
\text { mengikuti } \\
\text { kegiatan. }\end{array}$ & $\begin{array}{l}\text { Kegiatan } \\
\text { kaum difabel } \\
\text { terkendala } \\
\text { apabila tidak } \\
\text { ada failitas } \\
\text { ramah } \\
\text { difabel. }\end{array}$ \\
\hline $\begin{array}{l}\text { Sarana } \\
\text { transportasi }\end{array}$ & $\begin{array}{l}\text { Terdapat } \\
\text { transportasi } \\
\text { umum yang } \\
\text { dapat } \\
\text { digunakan } \\
\text { yaitu ojek dan } \\
\text { bus lokal. }\end{array}$ & $\begin{array}{l}\text { Transportasi } \\
\text { tidak } \\
\text { berjalan } 24 \\
\text { jam penuh. }\end{array}$ & $\begin{array}{l}\text { Memudahkan } \\
\text { wisatawan } \\
\text { dalam } \\
\text { berkunjung. }\end{array}$ & $\begin{array}{l}\text { Wisatawan } \\
\text { kesulitan } \\
\text { transportasi } \\
\text { bila kegiatan } \\
\text { selesai } \\
\text { melebihi jam } \\
\text { operasi } \\
\text { transportasi. }\end{array}$ \\
\hline $\begin{array}{l}\text { Papan petunjuk } \\
\text { arah }\end{array}$ & $\begin{array}{l}\text { Sudah ada } \\
\text { papan } \\
\text { petunjuk. }\end{array}$ & $\begin{array}{l}\text { Papan } \\
\text { petunjuk } \\
\text { hanya ada } \\
\text { pada satu } \\
\text { titik. }\end{array}$ & $\begin{array}{l}\text { Dapat } \\
\text { memudahkan } \\
\text { wisatawan } \\
\text { untuk menuju } \\
\text { tempat tujuan } \\
\text { bila petunjuk } \\
\text { arah jelas pada } \\
\text { segala arah. }\end{array}$ & $\begin{array}{l}\text { Wisatawan } \\
\text { banyak yang } \\
\text { tersesat. }\end{array}$ \\
\hline
\end{tabular}

Analisa Infrastruktur (Infrastructure)

Table 5. Analisa SWOT infrastruktur (infrastructure)

\begin{tabular}{|c|c|c|c|c|}
\hline $\begin{array}{l}\text { Infrastruktur } \\
\text { infrastructures) }\end{array}$ & $\begin{array}{l}\text { Kekuatan } \\
\text { (Strengths) }\end{array}$ & $\begin{array}{l}\text { Kelemahan } \\
\text { (Weakness) }\end{array}$ & $\begin{array}{l}\text { Peluang } \\
\text { (Opportunities) }\end{array}$ & $\begin{array}{l}\text { Ancaman } \\
\text { (Threatnesss) }\end{array}$ \\
\hline $\begin{array}{l}\text { Listrik atau } \\
\text { penerangan }\end{array}$ & $\begin{array}{l}\text { Listrik sudah } \\
\text { mengalir ke } \\
\text { seluruh } \\
\text { penjuru } \\
\text { desa. }\end{array}$ & $\begin{array}{l}\text { Masih banyak } \\
\text { titik jalan } \\
\text { yang tidak } \\
\text { ada } \\
\text { penerangan } \\
\text { sama sekali } \\
\text { dan sering } \\
\text { terjadi } \\
\text { pemadaman } \\
\text { bergilir. }\end{array}$ & $\begin{array}{l}\text { Pembuatan } \\
\text { alternatif } \\
\text { pengganti listrik } \\
\text { dengan SDA } \\
\text { yang ada, } \\
\text { sebagai listrik } \\
\text { sementara. }\end{array}$ & $\begin{array}{l}\text { Kegiatan akan } \\
\text { terkendala } \\
\text { bila listrik } \\
\text { mati dan tidak } \\
\text { ada supply } \\
\text { cadangan } \\
\text { listrik }\end{array}$ \\
\hline Pengairan & $\begin{array}{l}\text { Ketersediaan } \\
\text { air cukup } \\
\text { untuk } \\
\text { memenuhi } \\
\text { kebutuhan } \\
\text { masyarakat }\end{array}$ & $\begin{array}{l}\text { Air sungai } \\
\text { berkurang } \\
\text { saat kemarau } \\
\text { namun tidak } \\
\text { sampai habis } \\
\text { walaupun } \\
\text { sungai surut. }\end{array}$ & $\begin{array}{l}\text { Dapat dibuka } \\
\text { tempat wisata } \\
\text { baru sebagai } \\
\text { pendukung } \\
\text { wisata Rumah } \\
\text { Atsiri Indonesia. }\end{array}$ & $\begin{array}{l}\text { Kondisi alam } \\
\text { di musim } \\
\text { kemarau, } \\
\text { tidak } \\
\text { mendukung } \\
\text { kegiatan } \\
\text { wisata }\end{array}$ \\
\hline
\end{tabular}




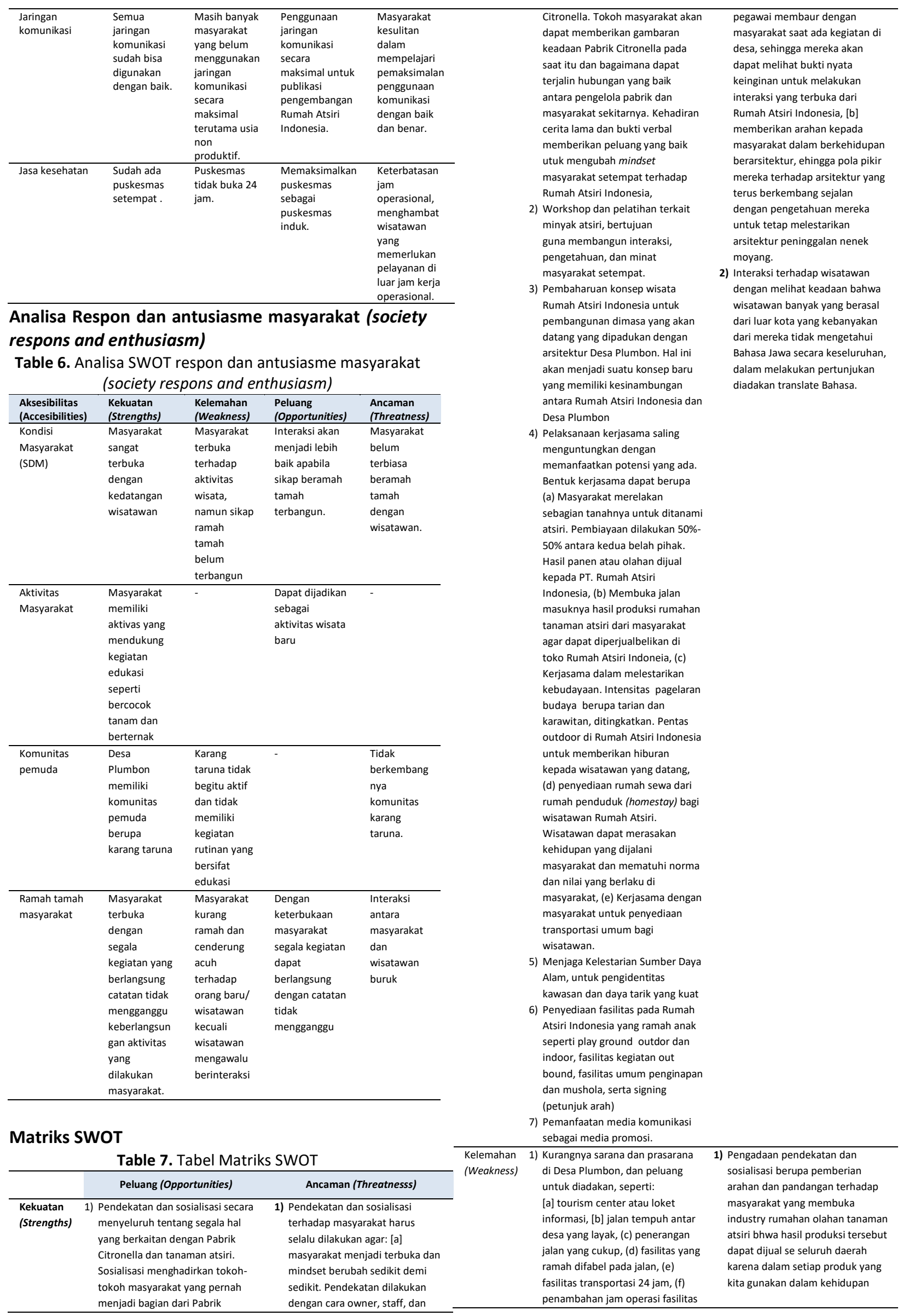




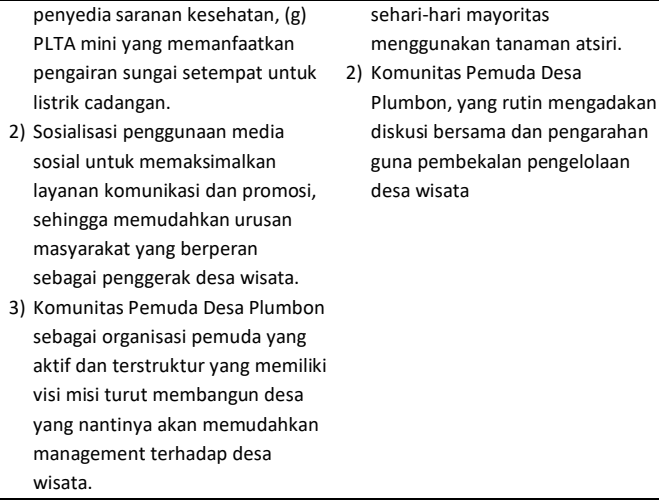

Berdasarkan analisis SWOT yang telah dilakukan dapat disimpulkan bahwa pengembangan Rumah Atsiri Indonesia sebagai wisata edukasi yang melibatkan peran masyarakat sebagai bentuk pemberdayaan memiliki visi misi yang selaras dengan Desa Plumbon. Prosentase keberhasilan lebih besar akan dicapai apabila terjadi keterlibatan masyarakat secara langsung di dalamnya. Keterlibatan masyarakat dapat memberikan inovasi terkait dengan pengembangan yang akan dilakukan, dan penyelesaian kendala-kendala yang dihadapi oleh Rumah Atsiri Indonesia dalam visi misinya mengembangkan wisata edukasi. Kerjasama yang baik sangat perlu diadakan, antara Rumah Atsiri Indonesia, masyarakat, dan pembuat kebijakan atau pejabat setempat saling berkerja sama guna mencapai visi misi yang sejalan. Kerjasama dapat memecahkan masalah dan memunculkan inovasi yang menjadi faktor pengembangan desa. Hal tersebut dapat dipetakan dalam skema seperti gambar 3 berikut ini:

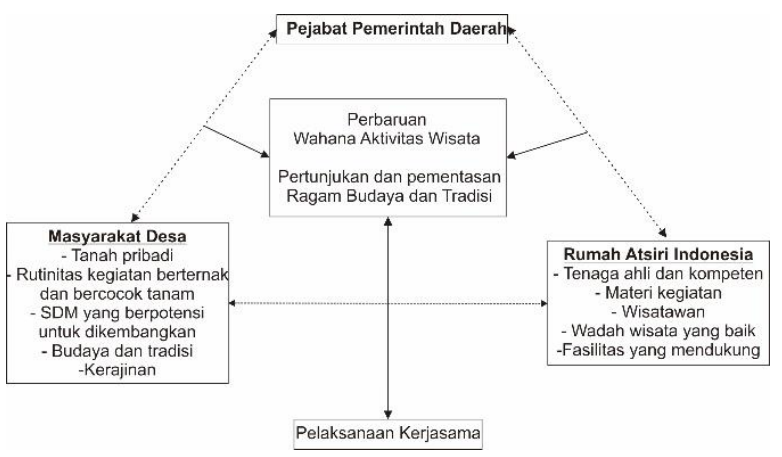

Gambar 3. Skema kerjasama pengembangan Rumah Atsiri (sumber: analisis penulis, 2018)

Aplikasi kerjasama masyarakat, Rumah Atsiri dan pemerintah setempat perlu diawali dengan beberapa langkah program, yang diusulkan berdasarkan analisis SWOT di atas:

1. Sosialisasi dan Interaksi, yang dilakukan guna mencapai hubungan interaksi yang aktif dan interaktif antara Rumah Atsiri Indonesia dan masyarakat. Sosialisasi yang dilakukan antara lain: (a) Pihak Rumah Atsiri ikut serta dalam acara kumpulan atau sarasehan rutin yang diadakan oleh setiap dusun. Kegiatan ini akan terlihat oleh masyarakat bagaimana antusiasme pihak Rumah Atsiri Indonesia dalam membina hubungan yang baik dengan masyarakat dalam upaya pengembangan desa, (b) Pelibatan masyarakat dalam acara grand opening Rumah Atsiri Indonesia, sehingga masyarakat desa dapat turut merasakan keberadaan dan mengetahui isi Rumah Atsiri Indonesia, (c) Sosialisasi perihal minyak atsiri termasuk berbagai upaya pengembangan dan pengolahan serta pemasarannya yang dilakukakan dalam pertemuan rutin terbuka setiap 1 bulan sekali, (d) Sosialisasi pemaksimalan penggunaan media elektronik dan media sosial guna menunjang kegiatan yang berlangsung di desa yang diadakan dalam pertemuan rutin terbuka setiap 2 bulan sekali, (e) Sosialisasi menghadapi wisatawan berguna untuk memberikan bekal terhadap masyarakat untuk berinteraksi secara langsung tanpa rasa malu. Interaksi ini meliputi keramah tamahan, saling tolong menolong dan gotong royong, untuk terjalin hubungan baik antara masyarakat dan wisatawan. Interaksi yang baik dapat memberikan kesan tersendiri kepada wisatawan yang singgah

2. Workshop dan Pelatihan, terdiri dari (a) Workshop dan pelatihan pembuatan produk minyak atsiri yang dilakukan setiap 4 bulan sekali. Workshop ini dapat dipadukan dengan kegiatan PKK fokus pada sasaran ibu-ibu PKK. (b) Workshop dan pelatihan petani desa guna memberikan gambaran dan pembekalan terhadap mereka terkait penanaman, perawatan dan pemenenan tanaman atsiri (c) Worshop dan pelatihan untuk lulusan baru anakanak SMA yang ada di Desa Plumbon. Yang bertujuan memberikan bekal aktivitas setelah lulus. Hal ini juga akan menguntungkan Rumah Atsiri Indonesia untuk memudahkan mencari calon staff atau pegawai di Rumah Atsiri Indonesia

3. Diskusi Bersama, antara lain: (a) Pengadaan rapat terbuka guna membentuk organisasi pengurus desa wisata. Rapat ini dilakukan setelah diadakan grand opening, (b) Diskusi bersama secara rutin dan terbuka guna membahas rencana jangka panjang pembentukan dan pengembangan desa wisata yang dilakukan setiap 1 bulan sekali. Diskusi dihadiri oleh semua masyarakat dan diutamakan para pemuda desa

4. Pelengkapan Fasilitas dan Infrastruktur, berupa perbaikan jalan desa, perataan persebaran area listrik guna penerangan jalan desa, pemberian signing pada rute atau track wisata, pemaksimalan fasilitas kesehatan dan P3K, pengadaan transportasi wisata yang memanfaatkan SDM desa. 
Program tersebut di atas dapat mencapai hasil sebagai berikut:

1. Pelaksanaan Kerjasama antara Rumah Atsiri Indonesia dan Desa Plumbon berupa (a) Pemanfaatan sebagian petak tanah tiap warga untuk ditanami atsiri. Bibit disediakan oleh pihak Rumah Atsiri Indonesia. Perawatan dilakukan secara pribadi oleh masing masing pemilik tanah. Setelah panen hasil panen disetorkan kepada Rumah Atsiri Indonesia untuk dibeli. Hal ini menguntungkan kedua belah pihak dengan membuka peluang pasar baru hasil panen bagi para petani dan Rumah Atsiri Indonesia tetap mendapatkan bahan baku secara teratur untuk produksi. Setiap tanah ini juga dimanfaatkan sebagai media pembelajaran bagi wisatawan untuk bercocok tanam dan berkebun, (b) Pembuatan pupuk kompos dari residu bahan yang telah digiling. Residu tersebut dijadikan pupuk yang digunakan oleh para petani untuk bercocok tanam, (c) Peluasan jangkauan distribusi dan pembentukan centra meubel, (d) Penyewaan rumah penduduk sebagai homestay untuk kegiatan live in bagi wisatawan, dengan tidak merusak arsitektur desa setempat, dan tidak mendirikan bangunan baru dengan fungsi penginapan. Pelaksanaan kegiatan live in ini di fokuskan pada Dukuh Watusambang yang merupakan dukuh terdekat dengan Rumah Atsiri Indonesia, (e) Penjualan hasil produksi mandiri milik masyarakat yang dijual oleh Rumah Atsiri Indonesia, yang berperan sebagai distributor, dan masyarakat sebagai produsen, (f) Pembukaan fasilitas transportasi wisata bekerjasama dengan masyarakat sebagai penyedia transportasi

2. Pertunjukan dan Pementasan Ragam Budaya dan Tradisi dengan (a) Pementasan tari dan karawitan yang diadakan secara ritun setiap 2 minggu sekali. $\mathrm{Hal}$ ini dapat menjadi peluang untuk mengntungkan semua pihak. Wisatawan dan masyarakat akan terhibur, masyarakat juga dapat membuka peluang untuk kegiatan jual beli di pementasan tersebut, dan Desa Plumbon serta Rumah Atsiri Indonesia memiliki kegiatan hiburan yang baru yang dapat menjadi peluang minat calon wisatawan dan minat wisatawan untuk singgah kembali. Pementasan tari dan karawitan ini bergilir pada dukuh yang memiliki potensi untuk melakukan penampilan dan setelah itu berujung pada penampilan di Rumah Atsiri Indonesia. Pementasan tersebut berkonsentrasi di Dukuh Tarukan, (b) Pementasan pagelaran wayang dan karawitan yang diadakan 2 bulan sekali. Pementasan pagelaran wayang dan karawitan ini bergilir pada dusun yang memiliki potensi untuk melakukan penampilan dan setelah itu berujung pada penampilan di Rumah Atsiri Indonesia, Pementasan tersebut berkonsentrasi di Dukuh Cumpleng dan Pakem

3. Perbaruan Wahana Aktivitas Wisata berupa (a) Wisata susur sungai, meliputi kegiatan susur sungai Desa Plumbon dan juga dapat berlangsung dengan kegiatan memancing, (b) Wisata game dan outbound, wisata ini berupa kegiatan game yang dipadukan dengan kegiatan outbound untuk mempererat kerjasama team dan sebagai media refreshing, (c) Wisata bercocok tanam dan berkebun, merupakan kegiatan bercocok tanam secara berkelompok yang berbaur langsung dengan kegiatan bercocok tanam para petani di Desa Plumbon, (d) Wisata kuliner, merupakan wisata menikmati makanan khas Desa Plumbon sembari berbelanja dan menikmati pemandangan pedesaan.

\section{KESIMPULAN}

Masyarakat Desa Plumbon sangat terbuka dan memungkinkan dilibatkan sebagai penggerak desa wisata edukasi, dengan pusat wisata adalah Rumah Atsiri Indonesia. Keterbukaan masyarakat dapat diawali dari keterlibatan pihak Rumah Atsiri Indonesia dalam semua kegiatan kemasyarakatan, baik kegiatan budaya, maupun kegiatan sosial. Saling terbuka dan saling melibatkan diri antara masyarakat, pihak Rumah Atsiri Indonesia dan pemerintah daerah setempat, akan memungkinkan Desa Plumbon menjadi desa wisata edukasi.

Beberapa langkah menuju pengembangan potensi wisata yang perlu dilakukan adalah: sosialisasi dan interaksi, workshop, diskusi bersama dan penyediaan fasilitas desa. Langkah tersebut dilakukan guna mewujudkan Desa Plumbon sebagai desa wisata, melalui: 1) pengembangan bekerjasama dengan masyarakat dalam penyediaan lahan dan produksi bahan baku yang menguntungkan keduabelah pihak, 2) pelestarian budaya tradisional setempat dengan pagelaran ragam budaya, 3) pengembangan wahana rekreasi dari potensi yang ada, seperti susur sungai, bercocok tanam dan wisata kuliner.

\section{DAFTAR PUSTAKA}

Broadbent, Geoffrey, 1980, Signs, Symbols and Architecture (with Richard Bunt and Charles Jencks), London, John Wiley \& Sons Inc.

Martiarini, Rimas. (2017). Strategi Pengembangan Desa Wisata Melalui Pemberdayaan Masyarakat Desa Ketenger Baturraden, 11-12.

Nuryanti, Wiendu. 1993. Concept, Perspective and Challenges, makalah bagian dari Laporan Konferensi Internasional mengenai Pariwisata Budaya. Yogyakarta: Gadjah Mada University Press. Hal. 2-3. 
Inskeep, Edward, 1991, Tourism Planning: An Integrated and Sustainable Development Approach, New York, Wiley.

PENABULU FOUNDATION. (2015). Kemitraan Pemerintah-Swasta-Komunitas [Online] http://penabulufoundation.org/kemitraanpemerintah-swasta-komunitas/. [diakses pada 2 Maret 2018]

Ritchie, Brent W, 2003, Managing Educational Tourism, Britania Raya, Channel View Publications.

Rodger, David, 1998, Leisure, learning and travel "Journal of Physical Education, Research and Dance" [Online]. https://shapeamerica.tandfonline.com/doi/ab s/10.1080/07303084.1998.10605532?journalC ode=ujrd20\#.Xbzn-5ozZnl. [diakses pada Maret 2018].

Sastrayuda, Gumelar (2010). Konsep Pengembangan Kawasan Agrowisata [Online]. http://id.scribd.com/doc/226410383/Pengem banganKawasan-Agro-Wisata. [diakses pada Maret 2018].

Spillane, James, 1994. Pariwisata Indonesia, Siasat Ekonomi dan Rekayasa Kebuadayaan. Yogyakarta. Kanisius. 